\title{
Co-chaperones are limiting in a depleted chaperone network
}

\author{
Lonneke Heldens • Ron P. Dirks • Sanne M. M. Hensen • Carla Onnekink • \\ Siebe T. van Genesen · François Rustenburg • Nicolette H. Lubsen
}

Received: 4 November 2009/Revised: 29 April 2010/ Accepted: 26 May 2010/Published online: 18 June 2010

(C) The Author(s) 2010. This article is published with open access at Springerlink.com

\begin{abstract}
To probe the limiting nodes in the chaperoning network which maintains cellular proteostasis, we expressed a dominant negative mutant of heat shock factor 1 (dnHSF1), the regulator of the cytoplasmic proteotoxic stress response. Microarray analysis of non-stressed dnHSF1 cells showed a two- or more fold decrease in the transcript level of 10 genes, amongst which are the (co-)chaperone genes HSP90AA1, HSPA6, DNAJB1 and HSPB1. Glucocorticoid signaling, which requires the Hsp70 and the Hsp90 folding machines, was severely impaired by dnHSF1, but fully rescued by expression of DNAJA1 or DNAJB1, and partially by ST13. Expression of DNAJB6, DNAJB8, HSPA1A, HSPB1, HSPB8, or STIP1 had no effect while HSP90AA1 even inhibited. PTGES3 (p23) inhibited only in control cells. Our results suggest that the DNAJ co-chaperones in particular become limiting in a depleted chaperoning network. Our results also suggest a difference between the transcriptomes of cells lacking HSF1 and cells expressing dnHSF1.
\end{abstract}

Keywords Heat shock factor 1 . Chaperones . Co-chaperones $\cdot$ Aging $\cdot$ Steroid hormone signalling

L. Heldens and R. P. Dirks contributed equally to this work.

L. Heldens - R. P. Dirks - S. M. M. Hensen - C. Onnekink ·

S. T. van Genesen · N. H. Lubsen $(\square)$

Department of Biomolecular Chemistry 271,

Radboud University Nijmegen, P.O. Box 9101,

6500 HB Nijmegen, The Netherlands

e-mail: N.Lubsen@science.ru.nl

F. Rustenburg

Section Micro Array Facility, Department of Pathology,

VU University Medical Center, Amsterdam, The Netherlands

\begin{abstract}
Abbreviations
HSF1 Heat shock factor 1

HSE Heat shock element

GRE Glucocorticoid-responsive element
\end{abstract}

\section{Introduction}

All cells contain an extensive network of chaperones which together maintain proteostasis, i.e. this network aids in the folding of the primary peptide chain, the refolding of unfolding proteins and the removal of misfolded proteins (for reviews, see [1-8]). Two of the major nodes in the network are the Hsp70 and Hsp90 folding machines. At the core of these machines are Hsp90 and Hsp70, the proteins that promote folding; the activity and substrate specificity is controlled by a number of co-factors and co-chaperones. For Hsp70 it is the DNAJ (Hsp40) proteins that determine substrate specificity. DNAJs also stimulate ATP hydrolysis by Hsp70. The human genome contains over 40 DNAJ genes [9-11]. Some of these are highly tissue specific, others may be dedicated to a particular substrate or cooperate only with a specific Hsp70 and some may be redundant [12]. The diversity of DNAJs does show that these are important determinants of the activity and specificity of the Hsp70 folding machine.

The chaperoning capacity of the cell is enhanced by additional chaperone synthesis as part of a proteotoxic stress response, either the heat shock response in the case of cytoplasmic stress or the unfolded protein response in the case of ER stress. That an increase in chaperones is required to combat proteotoxic stress suggests that under normal conditions the chaperone capacity of a cell is limiting. Indeed, exogenous expression of aggregation-prone 
proteins, such as proteins with an expanded glutamine tract (polyQ), is toxic unless chaperones are also overexpressed [13-17]. Cytoplasmic proteotoxic stress signals to heat shock factor 1 (HSF1), which then activates the transcription of a number of genes encoding a variety of chaperones, together known as the heat shock proteins. In the absence of stress, HSF1 is generally believed to be kept inactive in the cell by direct interaction with Hsp90, p23 and immunophilins (for reviews, see [18-20]). HSF1 null mice show the expected stress-related phenotypes, such as a complete lack of the heat shock response and the inability to develop thermotolerance. However, they also suffer from neuronal, developmental and germ cell defects [2126], which cannot be directly linked to the heat shock response and which strongly suggests that HSF1 also regulates gene expression under non-stress conditions. Microarray analysis resulted in the identification of 49 genes (19 related to immune response) that are expressed at reduced levels in HSF1 null fibroblasts compared with wild-type cells cultured under physiological conditions. The immune response of HSF1 null mice was shown to be severely impaired [27]. More recently, direct evidence for the stress-independent regulation of genes by HSF1 was provided in the cass of the multi-drug resistance gene 1 [28] and the IL-6 gene [29]. Furthermore, HSF1 inhibits heregulin-induced transcription in breast carcinoma cells [30].

A number of studies have shown that the quality of the heat shock response diminishes with aging [31-37], a decrease that may be the result of a decrease in the activity of the deacetylase SIRT1 [38]. Senescence of cultured human fibroblasts is accompanied with a diminishing heat shock response and a reduction in the affinity of HSF1 for the heat shock element (HSE; [34]). Aging-related failure of HSF1 will interfere with an organism's ability to combat cellular stress and increase the susceptibility to protein folding disease [6, 8, 13, 14, 39-41]. Moreover, with accumulating evidence showing that HSF1 also regulates gene expression under non-stress conditions (see above), its decline may already cause phenotypic defects in the absence of exogenous stress [3, 4].

Here, we have used a dominant negative HSF1 mutant to inhibit HSF1 activity. As expected, a number of chaperone and co-chaperone genes were downregulated by dnHSF1. To test which (co-)chaperone is limiting in dnHSF1-expressing and thus chaperone-depleted cells, we used the glucorticoid response to probe the chaperoning network. Maturation of the steroid hormone receptor is known to be controlled by both the Hsp70 and the Hsp90 folding machinery (for review, see [42]) and augmenting the chaperone network by either stress [43] or expression of a constitutively active HSF1 mutant [44] potentiates the glucocorticoid response. We show here that it is, unexpectedly, primarily the DNAJ (Hsp40) proteins which become limiting when the chaperoning network is depleted.

\section{Materials and methods}

\section{Recombinant DNA constructs}

Oligonucleotides that were used to generate recombinant DNA constructs are listed in Table 1. Plasmid pLmHSF1SN that contains the code for the HSF448 mutant was kindly donated by Dr. Wang [45]. The 1.36-kb XhoI fragment of pLmHSF1SN was cloned into pcDNA5-FRT/TO (Invitrogen), resulting in plasmid pcDNA5-HSF448. The code for the HSF1 mutant HSF379 was PCR amplified from pLmHSF1SN using the HSF379 primer set and cloned into the HindIII and XhoI sites of pcDNA5-FRT/TO, yielding plasmid pcDNA5-HSF379 (dnHSF1). The promoter constructs pGL3-HspB1 (-685/+36), pGL3-DnaJA1 (-464/ +167), pGL3-DnaJB1 (-508/+38), pGL3-Hsp90AA1 $(-188 /+18), \quad$ pGL3-ST13 $(-400 /+141), \quad$ pGL3-STIP1 $(-1264 /+145)$, pGL3-PTGES3 (-1108/+104), pGL3RMB23 (-1265/+189), pGL3-PMVK (-1183/+147), pGL3-BiP (-2742/+202), pGL3-CHOP $(-936 /+2)$, and pGL3-HSPA1A $(-313 /+196)$ were made by PCR amplifying the promoter fragments from human genomic DNA using the respective "prom" primer sets and cloning the fragments into pGL3-Basic (Promega). The expression plasmids pcDNA5-HSPB1, pcDNA5-HSPB8, pcDNA5ST13, pcDNA5-STIP1, and pcDNA5-PTGES3 were made by PCR amplifying the cDNAs from HEK293 RNA using the respective "exp" primer sets and cloning the cDNAs into pcDNA5-FRT/TO. Expression plasmids pcDNA5-V5DnaJA1, pcDNA5-V5-DnaJB1, pcDNA5-V5-DnaJB6, and pcDNA5-V5-DnaJB8 were kindly donated by J. Hageman (University of Groningen, The Netherlands; [46]). Expression construct pCMV-SPORT6-Hsp90AA1 was obtained from Imagenes (http://www.imagenes-bio.de). The Hsp90AA 1 coding sequence was completed at the $5^{\prime}$ end by inserting the corresponding fragment PCR amplified from human cDNA SacII-MscI. Plasmid pOTB7-STIP1 was obtained from Imagenes. The EcoRI (blunt)-XhoI fragment of pOTB7-STIP1 was cloned into the HindIII (blunt) and XhoI sites of pcDNA5-FRT/TO, resulting in plasmid pcDNA5-STIP1. The glucocorticoid-responsive reporter plasmid pGRE-Luc was made by annealing the GRE primer set and cloning the double stranded oligo into the NheI and BglII sites of pGL3-promoter (Promega). The Drosophila melanogaster Hsp70-luciferase reporter construct $\mathrm{pHL}$ and the Hsp70 expression construct were described earlier [47]. Plasmid pRL-CMV was obtained from Promega. All plasmid constructs were sequence verified. 
Table 1 Oligonucleotides that were used to generate recombinant DNA constructs

\begin{tabular}{|c|c|}
\hline Oligo name & Oligo sequence $\left(5^{\prime} \rightarrow 3^{\prime}\right)$ \\
\hline HSF379-for & agctaagcttaccatggatctgeccgtgggec \\
\hline HSF379-rev & agctctcgagctacaggcaggctacgctgaggc \\
\hline PMVKprom-for & agctaagcttactcaggtaaaacaggagatgtg \\
\hline PMVKprom-rev & agctccatggccaaacagatatggggagaaaag \\
\hline RBM23prom-for & agctctcgagtatccaagacccaaaggggcc \\
\hline RBM23prom-rev & agctccatggcagttccgggtccccgcag \\
\hline STIP1prom-for & agctaagcttgtggggcaggtggaattaaag \\
\hline STIP1prom-rev & agctccatggcgcagcgcggtccggaacc \\
\hline HSPB1prom-for & agtcgacaggcatgcaccaccatgcccagc \\
\hline HSPB1 prom-rev & accatggtggetgactctgctctggacgtctg \\
\hline ST13prom-for & agctaagcttcccttccggeggaggcg \\
\hline ST13prom-rev & agctccatggtagggaggtggtgg \\
\hline PTGES3prom-for & agctaagcttaataccttagtgcttattatgaagc \\
\hline PTGES3prom-rev & agctccatggtgaacggggcagggggacg \\
\hline DNAJA1prom-for & agtcgaccacgcgtgaaaaacagcaagac \\
\hline DNAJA1prom-rev & accatggtggctgaggccggtgtgtgaggga \\
\hline DNAJB1prom-for & aagtcgaccagacacaggttaggtagttcgtcc \\
\hline DNAJB1prom-rev & accatggeccectcctgcggeccgecga \\
\hline CHOPprom-for & tgagctctgtcacccaggctggagtgc \\
\hline CHOPprom-rev & tagatctctgacctcgggagcgcetggctg \\
\hline BiPprom-for & tctcgaggtatttttagtagagactgggcac \\
\hline BiPprom-rev & accatggtgccagccagttgggcagcag \\
\hline HSP90prom-for & agctaagcttgcgcaggcgctgttcctgg \\
\hline HSP90prom-rev & agctccatggcgeccggaggccacaccc \\
\hline HSPA1Aprom-for & aagatcttgaagcgcaggcggtcagca \\
\hline HSPA1Aprom-rev & aaagcttccggttccetgctctctgtc \\
\hline HSP90AA1exp-for & tccgcggtcacttagccaagatgcctg \\
\hline HSP90AA1exp-rev & tggccaatcatagagatatctgcacc \\
\hline HSPB1exp-for & agctaagcttaccatgaccgagcgecgcgtc \\
\hline HSPB1exp-rev & agctctcgagttacttggcggcagtctcatcg \\
\hline HSPB8exp-for & agctaagcttaccatggctgacggtcagatg \\
\hline HSPB8exp-rev & agctctcgagtcaggtacaggtgacttcetggct \\
\hline ST13exp-for & agctaagcttaccatggaccecegcaaagtg \\
\hline ST13exp-rev & agctaagcttaccatggacccccgcaaagtg \\
\hline PTGES3exp-for & agctggatccaccatgcagcetgcttctgcaaagtg \\
\hline PTGES3exp-rev & agctctcgagttactccagatctggcattttttc \\
\hline GRE-up & ctagcggtacattttgttctagaacaaaatgtaccggtacattttgttct \\
\hline GRE-low & gatctagaacaaaatgtaccggtacattttgttctagaacaaaatgtacc \\
\hline
\end{tabular}

Tissue culture, transfections, and reporter gene assays

Flp-In T-REx-293 cells (Invitrogen) were manipulated according to the manufacturer's instructions using the T-REx system (Invitrogen) to generate the stable cell lines HEK-HSF448, HEK-HSF379 and HEK-cDNA5 that carry a single copy of the tetracycline-inducible plasmids pcDNA5-HSF448, pcDNA5-HSF379, and pcDNA5-FRT/ TO, respectively. The cells were cultured at $37^{\circ} \mathrm{C} / 5 \% \mathrm{CO}_{2}$ in high glucose DMEM medium supplemented with $10 \%$ fetal calf serum and $100 \mathrm{U} / \mathrm{ml}$ penicillin and $100 \mu \mathrm{g} / \mathrm{ml}$ streptomycin. Blasticidin $(1.65 \mu \mathrm{g} / \mathrm{ml}$; Invitrogen) and $100 \mu \mathrm{g} / \mathrm{ml}$ hygromycin were also added to the culture medium during maintenance of the cell lines, but were omitted during experiments. Transient transfections were performed using FuGENE-6 (Roche) according to the manufacturer's instructions. Cells were seeded on 24-well plates and on the next day transfected with $\sim 0.2 \mu \mathrm{g}$ plasmid per well. For testing the heat shock response in stable HEK293 cell lines, cells were transfected with 
$160 \mathrm{ng} \mathrm{pHL}$, and $40 \mathrm{ng}$ pCMV-RL. At $48 \mathrm{~h}$ after transfection, cells were either left at $37^{\circ} \mathrm{C} / 5 \% \mathrm{CO}_{2}$ (control) or incubated at $45^{\circ} \mathrm{C}$ for $30^{\prime}$ (heat shock). After $6 \mathrm{~h}$ recovery at $37^{\circ} \mathrm{C} / 5 \% \mathrm{CO}_{2}$, cells were harvested for reporter gene analysis. For analysis of promoter activities, cells were transfected with a mixture of $160 \mathrm{ng}$ luciferase reporter plasmid and $40 \mathrm{ng} \mathrm{p} \beta$ actin- $\beta$-galactosidase or pCMV-RL per well. For testing glucocorticoid responsiveness, the culture medium of the cells was first replaced with medium supplemented with $10 \%$ steroid-free fetal calf serum (Hyclone), and then the cells were transfected with a mixture of $150 \mathrm{ng}$ pGRE-Luc and $50 \mathrm{ng} \mathrm{p} \beta$ actin- $\beta$-galactosidase per well. At $24 \mathrm{~h}$ after transfection, the culture medium was replaced with medium containing varying concentrations of dexamethasone (Centrafarm). At $48 \mathrm{~h}$ after transfection, cells were lysed in $200 \mu \mathrm{l}$ reporter lysis mix (25 mM Bicine, 0.05\% Tween 20, 0.05\% Tween 80) for $10 \mathrm{~min}$. For the $\beta$-galactosidase assay, $40 \mu \mathrm{l}$ cell lysate was mixed with $100 \mu \mathrm{l}$ Galacton solution $(100 \mathrm{mM}$ Na-phosphate $\mathrm{pH} 8.2,10 \mathrm{mM} \mathrm{MgCl}_{2}, 1 \%$ Galacton-Plus; Tropix). After $30 \mathrm{~min}$ incubation at room temperature, $150 \mu \mathrm{l}$ accelerator II (Tropix) was added and luminescence was measured with the Lumat LB 9507 tube luminometer (Berthold). For the luciferase assay, $40 \mu$ cell lysate was mixed with $50 \mu \mathrm{l}$ luciferin solution and luminescence was again measured with the Lumat luminometer. All reporter gene assays were performed in triplicate.

RNA isolation and microarray analysis

HEK-HSF379 or HEK-cDNA5 cells were either left untreated or treated with doxycyclin for $48 \mathrm{~h}$. Total RNA was isolated using Trizol according to the manufacturer's instructions (Invitrogen) and copied into Cy3-labeled (untreated cells) or Cy5-labeled (doxycyclin-treated cells) cRNA using the Agilent Low RNA Input Linear Amp Kit PLUS, or the reverse for the repeat array. Labeled cRNA samples were hybridized to an Agilent Whole Human Genome Microarray Kit $(4 \times 44 \mathrm{~K})$. The arrays were scanned using an Agilent Microarray Scanner. Image analysis and feature extraction were done with Feature Extraction (version 9.5.1, Agilent). Only genes that passed the GeneSpringGX standard quality control criteria (free trial available at http://www.genespring.com) were included in the analysis. We used a cut-off level of twofold changed expression (average signal intensity across the array) and an arbitrarily chosen signal cut-off of $>50$.

Western blot analysis

Cell pellets were homogenized in buffer containing $50 \mathrm{mM}$ Tris- $\mathrm{HCl} \mathrm{pH} 7.5,150 \mathrm{mM} \mathrm{NaCl}, 1 \%$ Triton X-100, $100 \mathrm{mM} \mathrm{NaF}, 20 \mathrm{mM} \mathrm{Na} \mathrm{P}_{2} \mathrm{O}_{7}, 1 \mathrm{mM}$ PMSF and protease inhibitors (Complete Mini; Roche). Then $4 \times$ sample buffer (200 mM Tris-HCl 6.8, 20\% $\beta$-mercaptoethanol, 8\% SDS, $40 \%$ Glycerol and $0.4 \%$ Bromophenolblue) was added and the lysates were incubated at $95^{\circ} \mathrm{C}$ for $5 \mathrm{~min}$. For detection of eIF $2 \alpha$ phosphorylation, samples were prepared as described [48]. Protein samples were separated in $12 \%$ polyacrylamide gels and transferred to nitrocellulose transfer membrane (Protran) using a Bio-Rad MiniPROTEAN II Electrophoresis cell according to the manufacturer's instructions. For western blot analysis, polyclonal HSF1 antibody (SPA-901; Stressgen) was used at a 1: 15,000 dilution, Hsp70 antibody 4G4 (ab5444; Abcam) was used at a 1:5,000 dilution, polyclonal DnaJB1 antibody (anti-Hsp40; SPA-400; Stressgen) at a 1:10,000 dilution, monoclonal Hsp90 antibody (610418, BD Biosciences) at a 1:1,000 dilution, HSPB1 antibody, obtained from Dr. A. Zantema, at a dilution of 1:400, monoclonal eIF2 $\alpha$ antibody was at a 1:500 dilution, polyclonal phosphorylated eIF2 $\alpha$ antibody (E2152; Sigma) was used at a 1:1,000 dilution, monoclonal V5 antibody (R96025; Invitrogen) was used at a 1:5,000 dilution, polyclonal ST13 antibody (ab13490; Abcam) at a 1:1,000 dilution, polyclonal STIP1 antibody (ab65046; Abcam) a 1:1,000 dilution, monoclonal p23 antibody (ab2814; Abcam) at a 1:1,000 dilution, polyclonal HSPB8 antibody, obtained from Dr. W. Boelens, at a dilution of 1:1,000, and monoclonal $\beta$-actin antibody (AC-15, Sigma-Aldrich) at a dilution of 1:5,000. Blots were incubated with fluorescent secondary antibodies IRDye ${ }^{\circledR} 800 \mathrm{CW}$ conjugated goat (polyclonal) Anti-Rabbit IgG and IRDye 680 conjugated goat (polyclonal) Anti-Mouse IgG. (926-32211 and 926-32220, respectively; LI-COR Biosciences) according to the manufacturer's instructions and scanned using a LI-COR Odyssey infrared scanner. Signals were quantified using Odyssey version 2.1 software.

\section{Results}

Dominant negative HSF1 mutants

To block HSF1 signaling in human HEK293 cells, we decided to use a dominant negative mutant reasoning that, given the interaction of HSF1 with other cellular components, the effect of a transcriptionally inactive mutant could well be different from the effect of HSF1 being completely absent. Two dominant negative HSF1 mutants containing, respectively, the first 379 (HSF379) and first 448 (HSF448) amino acids have been described (reviewed by [49]). HSF379 lacks both the potent trans-activation domain at the extreme $\mathrm{C}$-terminus and the weaker, more N-terminal, trans-activation domain, whereas HSF448 still has the weak trans-activation domain. The heat shock-mediated 


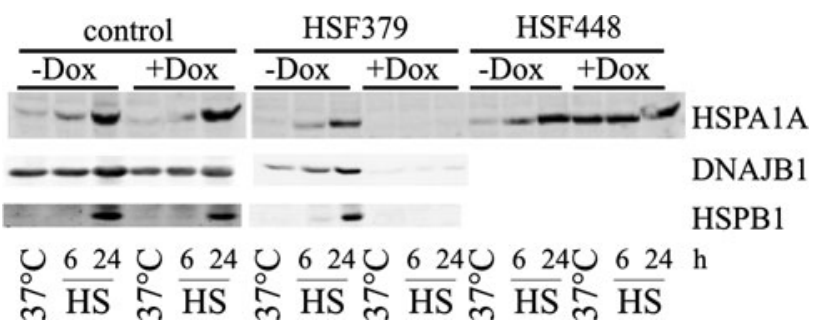

Fig. 1 The HSF1 mutants HSF379 and HSF448 have different effects on basal and heat shock-induced Hsp70 expression. Parental Flp-In HEK293 cells and HEK293 cells carrying a stably integrated copy of the pcDNA5-HSF379 (HEK-HSF379) or pcDNA5-HSF448 (HEK-HSF448) plasmid were cultured in the absence or presence of doxycycline. Cells were exposed to a heat shock $\left(30^{\prime}, 45^{\circ} \mathrm{C}\right)$, harvested at the indicated time point (h) after heat shock, and subjected to western blot analysis using an anti-Hsp70 antibody

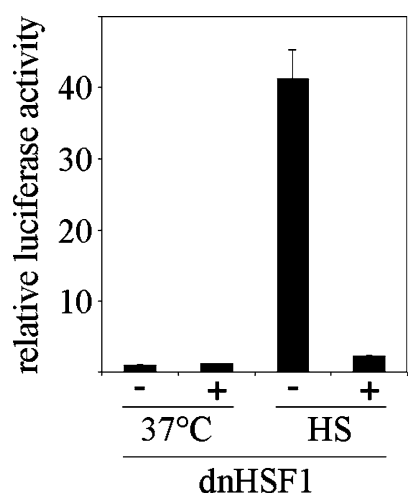

Fig. 2 The effects of dnHSF on basal and heat shock-induced activity of an Hsp70 promoter HEK293 cells carrying a stably integrated copy of the HSF379 (dnHSF1) were cultured in the absence $(-)$ or presence $(+)$ of doxycycline. Cells were transfected with a mixture of the Drosophila melanogaster Hsp70-luciferase reporter (pHL) and the Renilla Luciferase control plasmid pCMV-RL. At $48 \mathrm{~h}$ after transfection, cells were exposed to a heat shock of $30^{\prime}$ at $45^{\circ} \mathrm{C}$ (HS) or left at $37^{\circ} \mathrm{C}\left(37^{\circ} \mathrm{C}\right)$. When heat shocked, cells were allowed to recover for $6 \mathrm{~h}$ and harvested. Hsp70 promoter activities were determined by dividing firefly luciferase values by the corresponding renilla luciferase (experiments using the HSF448 line) or $\beta$-galactosidase (experiments using the dnHSF1 line) values to correct for varying transfection efficiencies. The relative luciferase activity in cells cultured at $37^{\circ} \mathrm{C}$ in absence of the various HSF1 mutants was set at 1 . The results are the average of three independent transfections (standard deviations are indicated by error bars)

induction of endogenous Hsp70 was completely abolished by HSF379, showing its potent dominant-negative activity (Fig. 1). Surprisingly, HSF448 was a very poor inhibitor of heat shock-mediated induction of Hsp70 (data not shown). Moreover, HSF448 caused a significant increase in the basal expression of Hsp70 (Fig. 1). Since this observation was in conflict with earlier data showing the dominantnegative activity of HSF448 [45], we tested the activities of both HSF1 mutants in a luciferase reporter gene assay. As expected, HSF379 completely inhibited the heat shockmediated induction of the D. melanogaster Hsp70 promoter (Fig. 2). In the experiments reported below, HSF379 was used to inhibit HSF1 activity and will be referred to as dnHSF1.

Transcriptome changes in the presence of dnHSF1

If HSF1 plays a role even in the absence of exogenous stress, then exogenous expression of a dominant-negative HSF1 mutant in unstressed cells should change the transcriptome. We therefore compared the transcriptomes of HEK cells with or without doxycycline and with or without dnHSF1 using a two-color 44K Agilent Human Expression Profile Array. The transcripts of only 10 genes showed a more than twofold lower level in the presence of dnHSF1 (Table 2 in bold, and Table 3). Four of these, namely HSPA6 (hsp70B'), HSP90AA1 (Hsp90), DNAJB1 (Hsp40), and HSPB1 (Hsp27), encode chaperones (Table 2 in bold). The steady state level of the corresponding proteins was also reduced in dnHSF1 expressing cells (Fig. 3; note that the HSPA6 mRNA level is very low in nonstressed HEK293 cells; [50]). Surprisingly, there was a distinct difference between dnHSF1 expressing cells and mouse embryonic fibroblasts lacking HSF1: the $h s f-/ h s f-$ MEFs contain wild type levels of Hsp90 and DNAJB1.

The levels of the transcripts of a number of other chaperone genes did not quite meet the "twofold" lower in the presence of dnHSF1 cut-off, but did come close (AHSA2, for example; Table 2). To test whether HSF responsiveness is a general property of genes encoding (co-)chaperones, we looked at the response of all known members of the HSP gene families (HSPH, HSPA, DNAJ, and HSPB) as well as other known (co-)chaperones coding genes expressed in HEK 293 cells (Table 2). Of the HSPA (Hsp70) genes, only HSPA6 responded strongly to dnHSF1. Similarly, very few members of the large DNAJ (Hsp40) family were downregulated by HSF1. This is rather surprising as the DNAJ proteins determine the substrate specificity, and stimulate the activity, of the Hsp70 folding machine and are thus critical nodes in the chaperoning network of the cell. Also, most of the Hsp70 and Hsp90 co-chaperones are not responsive to dnHSF1. For example, of the $14 \mathrm{Hsp} 90$ co-factors listed in a recent review [51], only the two AHA1 homologs as well as STIP1 and, to a lesser extent, ST13 responded strongly to dnHSF1 (Table 2).

To confirm the effect of HSF1 on the promoter activity of some of the genes downregulated by dnHSF1, we isolated the promoters and compared their activities in HEK-dnHSF1 cells and HEK-cDNA5 cells. The promoters of the STIP1, ST13, DNAJA1, DNAJB1 (see Table 2), and PMVK (selected because it is the strongest downregulated non-chaperone gene; Table 3) genes had significantly reduced activities in HEK-dnHSF1 cells compared with 
Table 2 Effect of exogenous expression of dnHSF1 on the transcript levels of the members of the families of heat shock proteins and their cochaperones

\begin{tabular}{|c|c|c|c|c|}
\hline \multirow[t]{2}{*}{ Gene name } & \multirow[t]{2}{*}{ Acc. no. } & \multicolumn{2}{|l|}{ dnHSF1/Ctrl } & \multirow[t]{2}{*}{ Alternative name } \\
\hline & & Ave & SD & \\
\hline \multicolumn{5}{|l|}{ HSPH family } \\
\hline HSPH1 & NM_006644 & 0.78 & 0.08 & Heat shock $105 \mathrm{kDa} / 110 \mathrm{kDa}$ protein 1 \\
\hline HSPH2 & NM_002154 & 0.66 & 0.04 & Heat shock $70 \mathrm{kDa}$ protein 4 \\
\hline HSPH3 & NM_014278 & 0.61 & 0.21 & Heat shock $70 \mathrm{kDa}$ protein 4 -like \\
\hline HSPH4 & NM_006389 & 1.19 & 0.33 & Hypoxia up-regulated 1 \\
\hline \multicolumn{5}{|l|}{ HSPA family } \\
\hline HSPA1A/B ${ }^{\mathrm{a}}$ & NM_005345 & 0.93 & 0.18 & hsp72 \\
\hline HSPA1L & NM_005527 & Not on array ${ }^{b}$ & Not on array ${ }^{b}$ & Heat shock $70 \mathrm{kDa}$ protein 1-like \\
\hline HSPA2 & NM_021979 & 1.22 & 0.20 & \\
\hline HSPA5 & NM_005347 & 1.18 & 0.35 & GRP78, BiP \\
\hline HSPA6 & NM_002155 & $0.46^{\mathrm{c}}$ & 0.10 & HSP70B $^{\prime}$ \\
\hline HSPA8 & NM_153201 & 0.87 & 0.08 & HSC70 \\
\hline HSPA9 & NM_004134 & 0.90 & 0.08 & Mortalin-2 (mitochondrial protein) \\
\hline HSPA12A & NM_025015 & 1.10 & 0.20 & KIAA0417 \\
\hline HSPA12B & NM_052970 & $\mathrm{nd}^{\mathrm{d}}$ & $\mathrm{nd}^{\mathrm{d}}$ & \\
\hline HSPA13 & NM_006948 & 0.57 & 0.53 & STCH \\
\hline HSPA14 & NM_016299 & 0.85 & 0.13 & \\
\hline \multicolumn{5}{|l|}{ HSP90 family } \\
\hline HSP90AA1 & NM_005348 & 0.38 & 0.06 & Hsp90 $\alpha$ \\
\hline HSP90AB1 & NM_007355 & 0.89 & 0.06 & Hsp90 $\beta$ \\
\hline HSP90B1 & NM_003299 & 1.16 & 0.36 & Grp94 \\
\hline TRAP1 & NM_016292 & 1.06 & 0.05 & $\begin{array}{l}\text { TNF receptor-associated protein } 1 \\
\quad \text { (mitochondrial Hsp90) }\end{array}$ \\
\hline \multicolumn{5}{|c|}{ DNAJ (Hsp40) family } \\
\hline DNAJA1 & NM_001539 & 0.64 & 0.10 & HDJ2 \\
\hline DNAJA2 & NM_005880 & 1.30 & 0.42 & \\
\hline DNAJA3 & NM_005147 & 1.00 & 0.13 & \\
\hline DNAJA4 & NM_018602 & $\mathrm{nd}^{\mathrm{d}}$ & $\mathrm{nd}^{\mathrm{d}}$ & \\
\hline DNAJB1 & NM_006145 & 0.25 & 0.05 & hsp40 \\
\hline DNAJB2 & NM_006736 & 0.60 & 0.07 & HSJ1 \\
\hline DNAJB3 & NM_001001394 & $\mathrm{nd}^{\mathrm{d}}$ & $\mathrm{nd}^{\mathrm{d}}$ & \\
\hline DNAJB4 & NM_007034 & 0.94 & 0.09 & \\
\hline DNAJB5 & NM_012266 & 0.97 & 0.10 & \\
\hline DNAJB6 & NM_005494 & 0.93 & 0.12 & \\
\hline DNAJB7 & NM_145174 & $\mathrm{nd}^{\mathrm{d}}$ & $\mathrm{nd}^{\mathrm{d}}$ & \\
\hline DNAJB8 & NM_153330 & $\mathrm{nd}^{\mathrm{d}}$ & $\mathrm{nd}^{\mathrm{d}}$ & \\
\hline DNAJB9 & NM_012328 & 1.22 & 0.17 & \\
\hline DNAJB11 & NM_016306 & 1.15 & 0.39 & \\
\hline DNAJB12 & NM_001002762 & 1.04 & 0.11 & \\
\hline DNAJB13 & NM_153614 & $\mathrm{nd}^{\mathrm{d}}$ & $n d^{d}$ & \\
\hline DNAJB14 & NM_024920 & 0.87 & 0.04 & \\
\hline DNAJC1 & NM_022365 & 1.17 & 0.23 & \\
\hline DNAJC2 & NM_014377 & 0.89 & 0.06 & Zuotin-related factor 1 (ZRF1) \\
\hline DNAJC3 & NM_006260 & 0.97 & 0.18 & \\
\hline DNAJC4 & NM_005528 & $0.99^{\mathrm{d}}$ & 0.10 & \\
\hline DNAJC5 & NM_025219 & $n d^{\mathrm{d}}$ & $\mathrm{nd}^{\mathrm{d}}$ & Cysteine string protein (CSP) \\
\hline DNAJC5B & NM_033105 & $\mathrm{nd}^{\mathrm{d}}$ & $\mathrm{nd}^{\mathrm{d}}$ & Cysteine string protein beta (CSP-beta) \\
\hline
\end{tabular}


Table 2 continued

\begin{tabular}{|c|c|c|c|c|}
\hline \multirow[t]{2}{*}{ Gene name } & \multirow[t]{2}{*}{ Acc. no. } & \multicolumn{2}{|c|}{ dnHSF1/Ctrl } & \multirow[t]{2}{*}{ Alternative name } \\
\hline & & Ave & SD & \\
\hline DNAJC5G & NM_173650 & $1.05^{\mathrm{c}}$ & 0.07 & \\
\hline DNAJC6 & NM_014787 & $0.87^{\mathrm{c}}$ & 0.18 & \\
\hline DNAJC7 & NM_003315 & 1.01 & 0.15 & \\
\hline DNAJC8 & NM_014280 & 0.92 & 0.06 & \\
\hline DNAJC9 & NM_015190 & 0.98 & 0.10 & \\
\hline DNAJC10 & NM_018981 & 1.11 & 0.24 & \\
\hline DNAJC11 & NM_018198 & 1.12 & 0.14 & \\
\hline DNAJC12 & NM_021800 & 1.05 & 0.19 & \\
\hline DNAJC13 & NM_015268 & 0.99 & 0.17 & \\
\hline DNAJC14 & NM_032364 & 1.08 & 0.16 & \\
\hline DNAJC15 & NM_013238 & 0.68 & 0.24 & \\
\hline DNAJC16 & NM_015291 & 1.09 & 0.10 & \\
\hline DNAJC17 & NM_018163 & 1.04 & 0.11 & \\
\hline DNAJC18 & NM_152686 & 0.99 & 0.14 & \\
\hline DNAJC19 & NM_145261 & 0.99 & 0.13 & \\
\hline DNAJC20 & NM_172002 & $1.07^{\mathrm{c}}$ & 0.12 & J-type co-chaperone HSC20 (RP3-366L4.2) \\
\hline DNAJC21 & NM_194283 & 0.79 & 0.18 & DnaJA5 \\
\hline DNAJC22 & NM_024902 & 1.06 & 0.08 & Hypothetical protein FLJ13236 \\
\hline DNAJC23 & NM_007214 & 0.98 & 0.08 & SEC63 \\
\hline DNAJC24 & NM_181706 & 0.87 & 0.11 & ZCSL3 \\
\hline DNAJC25 & NM_001015882 & 0.99 & 0.08 & DnaJ-like protein (bA16L21.2.1) \\
\hline DNAJC26 & NM_005255 & 1.07 & 0.19 & Cyclin G associated kinase (GAK) \\
\hline DNAJC27 & NM_016544 & 0.98 & 0.10 & Ras-associated protein Rap1 (RBJ) \\
\hline DNAJC28 & NM_017833 & $0.73^{\mathrm{c}}$ & 0.18 & C21orf55 \\
\hline DNAJC29 & NM_014363 & 0.93 & 0.04 & Sacsin \\
\hline DNAJC30 & NM_032317 & 1.04 & 0.06 & WBSCR18 \\
\hline \multicolumn{5}{|c|}{ HSPB (sHsp) family } \\
\hline HSPB1 & NM_001540 & 0.29 & 0.13 & Hsp27 \\
\hline HSPB2 & NM_001541 & $\mathrm{nd}^{\mathrm{d}}$ & $\mathrm{nd}^{\mathrm{d}}$ & MKBP \\
\hline HSPB3 & NM_006308 & $\mathrm{nd}^{\mathrm{d}}$ & $\mathrm{nd}^{\mathrm{d}}$ & \\
\hline HSPB4 & NM_000394 & $\mathrm{nd}^{\mathrm{d}}$ & $\mathrm{nd}^{\mathrm{d}}$ & $\alpha \mathrm{A}$-crystallin (CRYAA) \\
\hline HSPB5 & NM_001885 & $0.99^{\mathrm{c}}$ & 0.18 & $\alpha \mathrm{B}$-crystallin (CRYAB) \\
\hline HSPB6 & NM_144617 & $1.04^{\mathrm{d}}$ & 0.25 & Hsp20 \\
\hline HSPB7 & NM_014424 & $\mathrm{nd}^{\mathrm{d}}$ & $\mathrm{nd}^{\mathrm{d}}$ & cvHsp \\
\hline HSPB8 & NM_014365 & $\mathrm{nd}^{\mathrm{d}}$ & $\mathrm{nd}^{\mathrm{d}}$ & HSP22 \\
\hline HSPB9 & NM_033194 & 0.68 & 0.20 & \\
\hline HSPB 10 & NM_024410 & $\mathrm{nd}^{\mathrm{d}}$ & $\mathrm{nd}^{\mathrm{d}}$ & ODF1 \\
\hline \multicolumn{5}{|l|}{ Others } \\
\hline HSPD1 & NM_002156 & 0.88 & 0.17 & Hsp60, chaperonin \\
\hline HSPE1 & NM_002157 & 0.73 & 0.08 & Hsp10, chaperonin 10 \\
\hline SERPINH1 & NM_001235 & 0.55 & 0.08 & Hsp47 \\
\hline ССТ3 & NM_005998 & 0.67 & 0.17 & TCP1, subunit 3 (gamma) \\
\hline \multicolumn{5}{|l|}{ Co-chaperones } \\
\hline AHSA1 & NM_012111 & 0.63 & 0.07 & AHA1 homolog 1 \\
\hline AHSA2 & NM_152392 & 0.51 & 0.04 & AHA1 homolog 2 \\
\hline BAG1 & NM_004323 & 1.03 & 0.16 & \\
\hline BAG2 & NM_004282 & 1.10 & 0.13 & \\
\hline
\end{tabular}


Table 2 continued

\begin{tabular}{lllll}
\hline Gene name & Acc. no. & dnHSF1/Ctrl & & Alternative name \\
\cline { 2 - 4 } & & Ave & SD & \\
\hline BAG3 & NM_004281 & 1.31 & 0.18 & \\
BAG4 & NM_004874 & $1.28^{\mathrm{c}}$ & 0.43 & \\
BAG5 & NM_001015049 & 0.99 & 0.17 & p23 \\
PTGES3 & NM_006601 & 0.88 & HIP \\
ST13 & NM_003932 & 0.63 & HOP \\
STIP1 & NM_006819 & 0.53 & 0.08 & CHIP \\
STUB1 & NM_005861 & 0.97 & 0.06 & \\
AIP & NM_003977 & 0.94 & 0.21 & nd \\
CDC37 & NM_007065 & nd & \\
FKBP4 & NM_002014 & 1.00 & 0.23 & Cyclophilin D \\
FKBP5 & NM_004117 & 0.98 & 0.07 & \\
PPID & NM_005038 & 0.97 & 0.08 & \\
PPP5C & NM_006247 & 1.21 & 0.30 & \\
SGTA & NM_003021 & 1.14 & 0.24 & \\
TOMM70A & NM_014820 & 1.11 & 0.25 & 0.04 \\
TTC4 & NM_004623 & 1.00 & 0.07 & \\
UNC45A & NM_018671 & 0.99 & & \\
\hline
\end{tabular}

a The array oligonucleotides do not discriminate between the transcripts of these two genes

b None of the oligonucleotides on the array hybridize with the transcript of this gene

c The hybridization signal was significant but below 100

d The hybridization signal was not significant

Table 3 Non-chaperone encoding genes downregulated by dnHSF1

\begin{tabular}{lllll}
\hline Gene name & Acc. no. & \multicolumn{2}{l}{ dnHSF1/Ctrl } & Description \\
\cline { 3 - 4 } & & Av. & SD & \\
\hline PMVK & NM_006556 & 0.21 & 0.07 & Phosphomevalonate kinase \\
KLRG1 & NM_005810 & 0.35 & 0.14 & Killer cell lectin-like receptor subfamily G, member 1 \\
CDKL3 & NM_016508 & 0.39 & 0.17 & Cyclin-dependent kinase-like 3 \\
KA21 & NM_152349 & 0.41 & 0.32 & Truncated type I keratin KA21 \\
ZNF473 & NM_015428 & 0.48 & 0.07 & Zinc finger protein 473 \\
MLH1 & NM_000249 & 0.50 & 0.17 & mutL homolog 1 \\
\hline
\end{tabular}

control cells, whereas the promoters of the unfolded protein response target genes $\mathrm{CHOP}$ and $\mathrm{BiP}$, two genes with similar expression levels in HEK-dnHSF1 and control cells, were not or only slightly affected by dnHSF (Fig. 4). Note that these promoter activities were measured in unstressed cells, explaining why the activity of the promoters of the two canonical heat stress-inducible HSPA1A (Hsp70) gene is only inhibited by about $50 \%$; note also that the activities of isolated promoter regions do not necessarily reflect the activity of the endogenous promoter which could also be controlled by chromatin structure and/or elements lacking from the isolated promoter region. The HSPB 1 gene, for example, has been reported to also have heat shock elements in its first intron [52].
Lack of heat shock proteins could cause stress in the cells, which in turn could activate a non-HSF-dependent stress response (see also [53]). To determine whether exogenous expression of dnHSF1 caused stress, we determined whether expression of dnHSF1 is associated with an increased level of phosphorylated eIF $2 \alpha$. Activation of eIF $2 \alpha$ kinases is a common response to a variety of stresses (for review, see [54]). As shown in Fig. 5, the basal level of eIF $2 \alpha$ phosphorylation is not increased by the expression of dnHSF1. In addition, the decay of eIF $2 \alpha$ phosphorylation after a heat shock is not notably affected by expression of dnHSF1 (Fig. 5). This is in accordance with previous reports showing that cells lacking HSF1 are not impaired in their ability to recover 


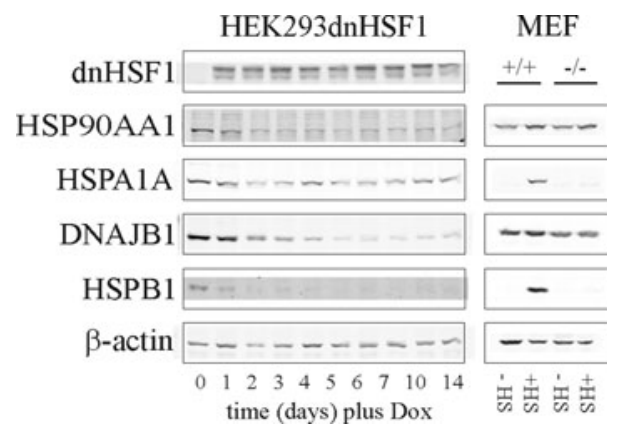

Fig. 3 Left panel the decay of heat shock protein levels during expression of dnHSF1. HEK-HSF379 cells were treated with doxycyclin for the time indicated and harvested. Right panel the level of heat shock proteins in MEF wild-type cells $(+/+)$ and MEF cells lacking HSF1 (-/ - ) either before ( - HS) or after heat shock and recovery $(+\mathrm{HS})$. Cell lysates were subjected to SDS-PAGE and western blot analysis using the indicated antibodies

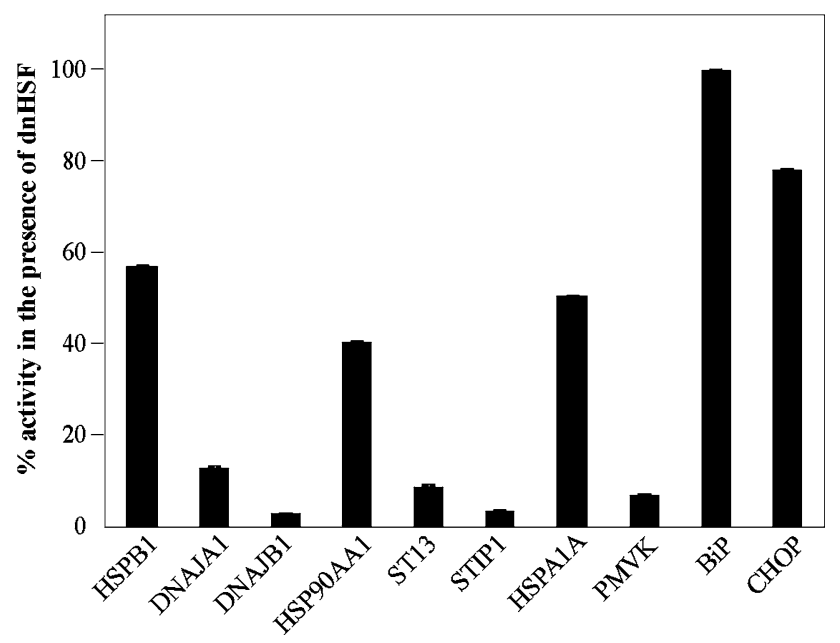

Fig. 4 Inhibition of promoter activity by dnHSF1. Control HEKcDNA5 cells and HEK-HSF379 cells were treated with doxycyclin. After 3 days, cells were transfected with the indicated promoter reporter constructs (see also "Materials and methods") and a $\beta$ actin$\beta$ gal reporter. At $48 \mathrm{~h}$ after transfection, cells were harvested and assayed for reporter gene activities. Promoter activities were determined by dividing luciferase values by the corresponding $\beta$-galactosidase values to correct for varying transfection efficiencies. The bars correspond to the \% activity of the promoter in the HEKHSF379 cells compared with the control HEK-cDNA5 cells. The results are the average of three independent transfections (standard deviations are indicated by error bars)

from heat stress, but do not built up thermostability after a heat stress $[26,55]$.

Glucocorticoid signalling is impaired by dnHSF1 and can be rescued by individual co-chaperones

Expression of dnHSF1 depletes the cell of a number of chaperones and is predicted to decrease the activity of both the Hsp70 and the Hsp90 folding machine. Both are known to be important for maturation and function of steroid

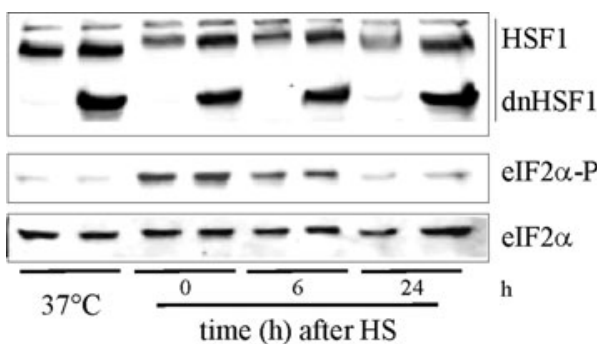

Fig. 5 The effect of exogenous expression of dnHSF1 on eIF $2 \alpha$ phosphorylation. HEK-cDNA5 cells and HEK-HSF379 cells were treated with doxycyclin for $48 \mathrm{~h}$. Cells were then exposed to a heat shock of $30^{\prime}$ at $45^{\circ} \mathrm{C}(\mathrm{HS})$ or left at $37^{\circ} \mathrm{C}\left(37^{\circ} \mathrm{C}\right)$. When heat shocked, cells were allowed to recover for the indicated time before harvesting. Cell lysates were subjected to SDS-PAGE and western blot analysis using the indicated antibodies

hormone receptors (reviewed in [42], [56]) and we thus examined whether expression of dnHSF1 resulted in impaired glucocorticoid hormone signaling. A synthetic glucocorticoid-responsive element (GRE) was linked to a luciferase reporter and used to monitor the response of HEK-dnHSF1 and HEK-cDNA5 cells to increasing concentrations of dexamethasone. Dexamethasone inducibility of the GRE was at least 50\% inhibited in HEK-dnHSF1 cells compared with HEK-cDNA5 cells (Fig. 6). At $10^{-6} \mathrm{M}$ dexamethasone, activity of the GRE was induced by ninefold in HEK-cDNA5 cells and only by fourfold in HEK-dnHSF1 cells and, at the highest concentration of dexamethasone, the inducibility in HEK-cDNA5 cells was even 13-fold compared with only fivefold in HEK-dnHSF1 cells.

If the impaired dexamethasone inducibility in the presence of dnHSF1 is due to a reduction in the expression levels of one or more (co-)chaperone genes, then it should be possible to rescue the glucocorticoid inducibility of the GRE in HEK-dnHSF1 cells by exogenous expression of those (co-)chaperones. We therefore tested the effect of exogeneous expression of different proteins on the glucocorticoid response of the pGRE-Luc reporter in HEKdnHSF1 cells (Figs. 7 and 8). The chaperone of which the expression is most affected by dnHSF1 is HSPB1. Although HSPB1 is not directly involved in the maturation of the glucocorticoid receptor, its lack may cause overloading of part of the folding network of the cell. However, exogenous expression of HSPB1 or of another sHsp, HSPB8, had no effect (Fig. 7). The level of Hsp90 is also affected by dnHSF1 but is apparently not limiting in the glucocorticoid response, as exogenous expression of Hsp90 was even inhibitory (Fig. 7). PTGES3 (p23) inhibited the GRE response in HEK-cDNA5 cells (Table 4) as previously reported [57, 58] but increased it slightly in HEKdnHSF1cells. STIP1 (Hop), which is a co-chaperone of Hsp90 as well as of Hsp70, however, had no effect, either 


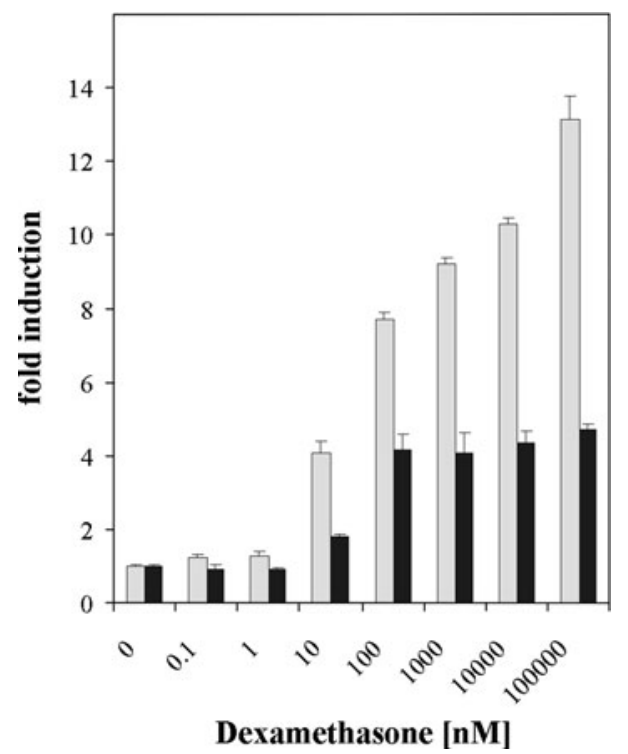

Fig. 6 Exogenous expression of dnHSF1 reduces the glucocorticoid response. Control HEK-cDNA5 cells and HEK-HSF379 cells were treated with doxycyclin. After 3 days, cells were transfected with a glucocorticoid-responsive luciferase reporter (pGRE-Luc) and a $\beta$ actin- $\beta$ gal reporter. At $24 \mathrm{~h}$ after transfection, cells were either left untreated or exposed to the indicated concentrations of dexamethasone. At $48 \mathrm{~h}$ after transfection, cells were harvested and assayed for reporter gene activities. Promoter activities were determined by dividing luciferase values by the corresponding $\beta$-galactosidase values to correct for varying transfection efficiencies. The bars correspond to the activity of the glucocorticoid-responsive promoter in the presence of dexamethasone compared to the activity in untreated cells, which was set at $100 \%$. Gray bars show the results for control HEK-cDNA5 cells, black bars those for HEK-HSF379 cells. The results are the average of three independent transfections (standard deviations are indicated by error bars)

in HEK-cDNA5 (Table 4) or in HEK-dnHSF cells (Fig. 7). In contrast, ST13 (Hip), an Hsp70 co-chaperone, did restore dexamethasone inducibility to almost the wild-type level in HEK-dnHSF cells. Even more effective was exogenous expression of the Hsp70 co-chaperones DNAJA1 (HDJ2) or DNAJB1 (Hsp40): this resulted in even higher dexamethasone inducibility in HEK-dnHSF1 cells compared with HEK-cDNA5 cells (Fig. 7). The rescue effect of DNAJA1 and DNAJB1 was not a general property of Hsp40 family members, since two other members of the DNAJB family, DNAJB6 and DNAJB8, did not show any rescue activity (Fig. 7). Expression of Hsp70 (HSPA1A) itself had no effect (Fig. 7; note that neither overexpression of DNAJ proteins nor overexpression of HSPA1A in HEK-cDNA5 cells affected the GRE response; see Table 4). These data show that it is the primary folding of the glucocorticoid receptor by the Hsp70 machinery that is most affected in HEK-dnHSF1 cells. As predicted by the wild-type level of DNAJB1 in hsfl-/hsfl- MEFs, these cells showed a wild-type glucocorticoid response (data not shown).

\section{Discussion}

Comparison of the transcriptome of embryonic fibroblasts from HSF1 null mice with that of wild-type cells identified 49 genes (19 related to immune response) that were not upregulated by a heat shock in wild-type cells but nevertheless were expressed at reduced levels in HSF1 null fibroblasts [27]. When HSF1 was depleted by RNA interference in HeLa cells, the expression level of 378 genes changed significantly in the absence of stress [59]. The main effect, surprisingly, was an increase in expression; for $80 \%$ of the affected genes, the transcript level increased. In contrast, we found no significant increase in expression in response to dnHSF1; dnHSF1 reduced the expression level of only 10 genes more than twofold, with a lesser effect on a number of chaperone encoding genes (Tables 2 and 3). The difference between the effect of depleting HSF1 in MEFs and HeLa cells is very likely to be caused by the far greater dependence of transformed cells on HSF1 [60]. HEK293 are less dependent on HSF1 than HeLa cells [60], but more so than MEFs. The response to blocking HSF1 in HEK293 cells might then be expected to be intermediate in the effect on the transcriptome but it is not. Clearly there is a difference between depleting HSF1 and expressing a dominant negative mutant. In part, this difference may be due to a secondary effect: depletion of HSF1 would free the chaperones which are usually complexed with HSF1 while dnHSF1 might capture more chaperones. More importantly is probably the activity of HSF1 as a repressor of transcription. Recently, it has been shown that HSF1 binds to MTA1, a co-repressor, to form a complex repressing estrogen-dependent transcription in breast carcinoma cells [30]. Similarly, HSF1 has been reported to interact with $\mathrm{C} / \mathrm{EBP} \beta$, an interaction which represses transcriptional activation [61]. The loss of HSF1 would release repression; expression of dnHSF1 could maintain it.

Expression of dnHSF1 is an efficient way of reducing the chaperoning capacity of the cell, as evidenced by the loss of the basal glucocorticoid response. Since the expression of so many genes playing roles at several stages of glucocorticoid receptor processing was suppressed in HEK-dnHSF1 cells, we did not expect that overexpression of individual proteins would rescue the glucocorticoid response. Nonetheless, the individual co-chaperones DNAJA1, DNAJB1 and ST13/Hip were able to fully rescue the dnHSF-mediated inhibition of the glucocorticoid response; PTGES3/p23 had some effect, whereas over expression of Hsp90, or STIP1/Hop had no effect. Hsp90 was even inhibitory (Fig. 7). Both DNAJ and ST13/Hop are co-chaperones of $\mathrm{Hsp} 70$ and function in the primary folding of the glucocorticoid receptor, but at different levels: DNAJ activates the ATPase of Hsp70, whereas ST13/Hip stabilizes the Hsp70-ADP state (reviewed 


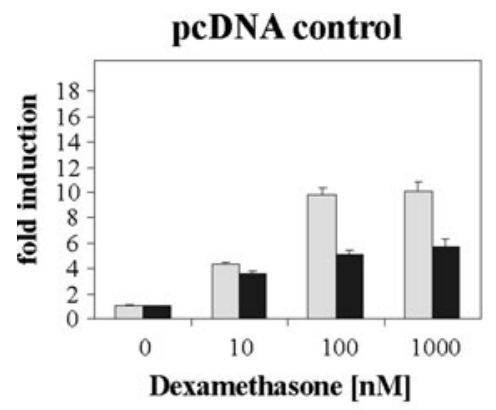

HSP90AA1

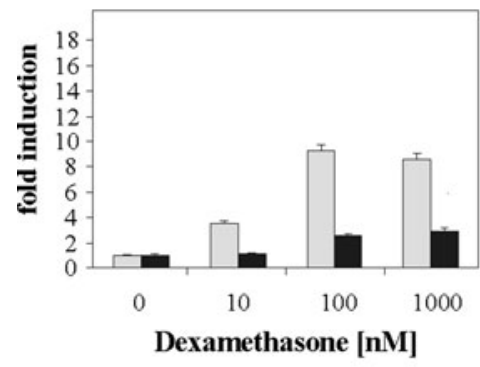

ST13/Hip

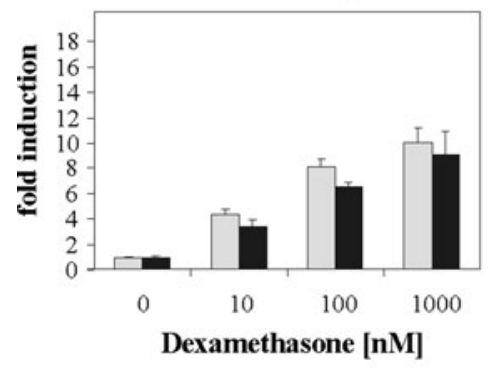

DNAJB6

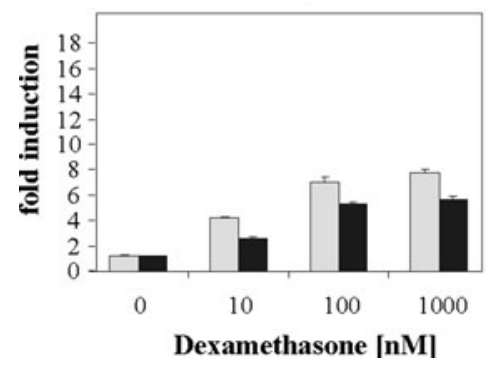

HSPB1

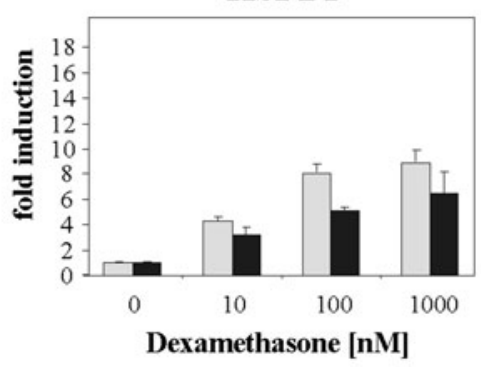

PTGES3/p23

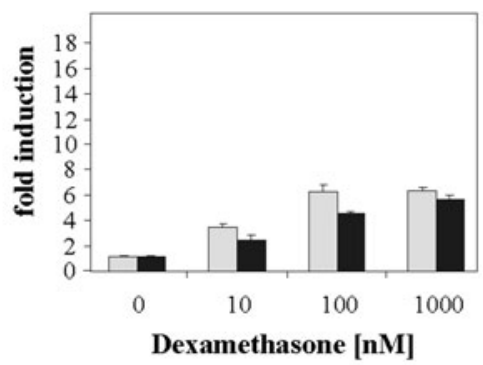

DNAJA1

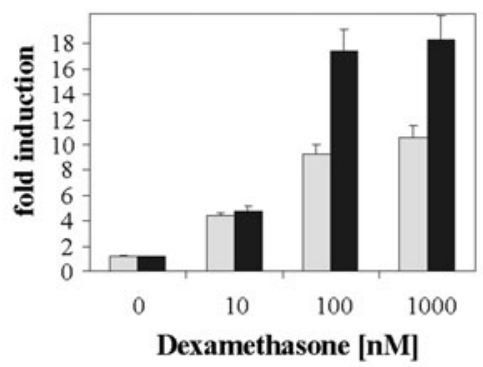

DNAJB8

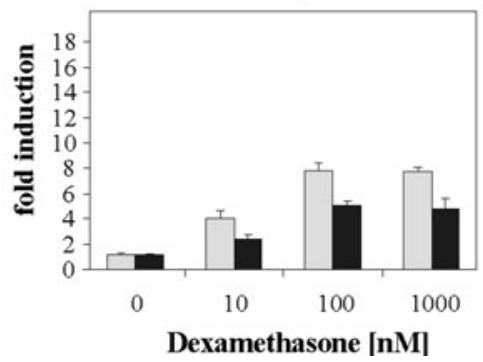

HSPB8

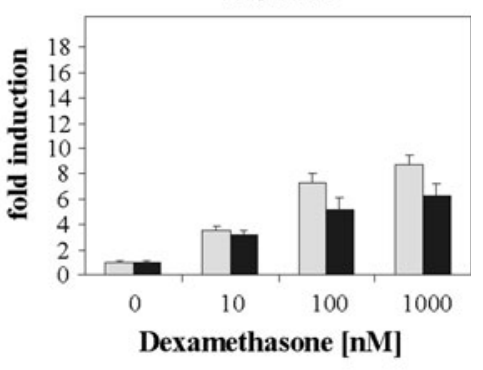

STIP1/Hop

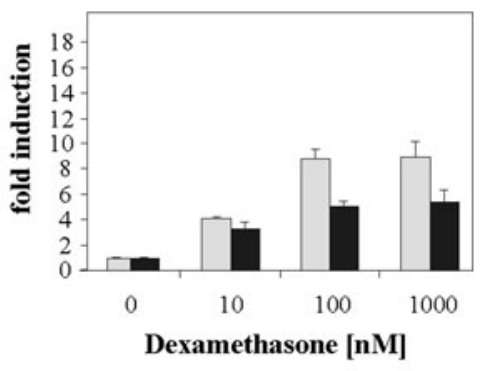

DNAJB1

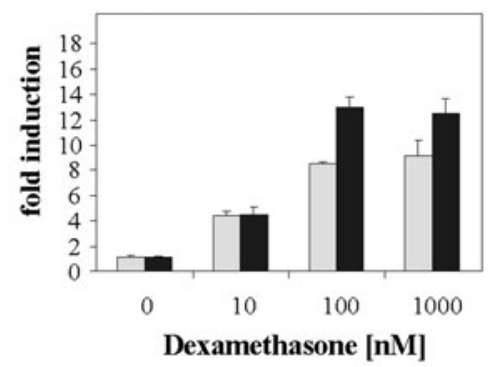

HSPA1A

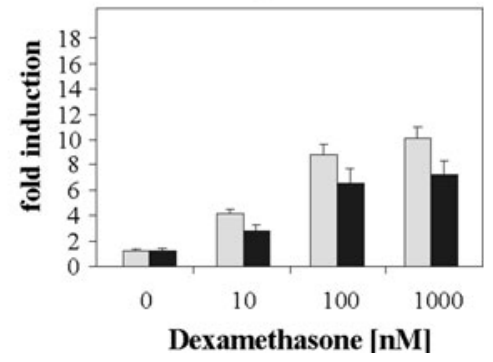

Fig. 7 Effect of overexpression of (co-)chaperones on glucocorticoid signaling in HEK-cDNA5 and HEK-dnHSF1 cells. Control HEKcDNA5 cells (light gray bars) and HEK-HSF379 cells (black bars) were treated with doxycyclin. After 3 days, cells were transfected with a mixture $(4: 1: 5)$ of glucocorticoid-responsive luciferase reporter (pGRE-Luc), a $\beta$ actin- $\beta$ gal reporter, and the expression construct indicated. At $24 \mathrm{~h}$ after transfection, cells were either left untreated or exposed to the indicated concentrations of dexamethasone. At $48 \mathrm{~h}$ after transfection, cells were harvested and assayed for reporter gene activities. Relative luciferase activities and -fold induction were determined as described in the legend to Fig. 6. Standard deviations are indicated by the error bars by [42]). Apparently, overexpression of DNAJA1 or DNAJB1 can compensate for a shortage of ST13/Hip and vice versa, as exogenous expression of either protein restores glucocorticoid sensitivity. Together, these data show that the limiting node of chaperoning network in dnHSF1-expressing cells is the Hsp70 folding machine, which is in turn is limited not by the level of Hsp70 itself but rather by its co-chaperones. In vitro folding studies of the glucocorticoid receptor have shown that DNAJB1 is required in catalytic amounts [62]. Our data also show that a lack of DNAJB1 can be compensated for by overexpression of DNAJA1. Functional redundancy between 


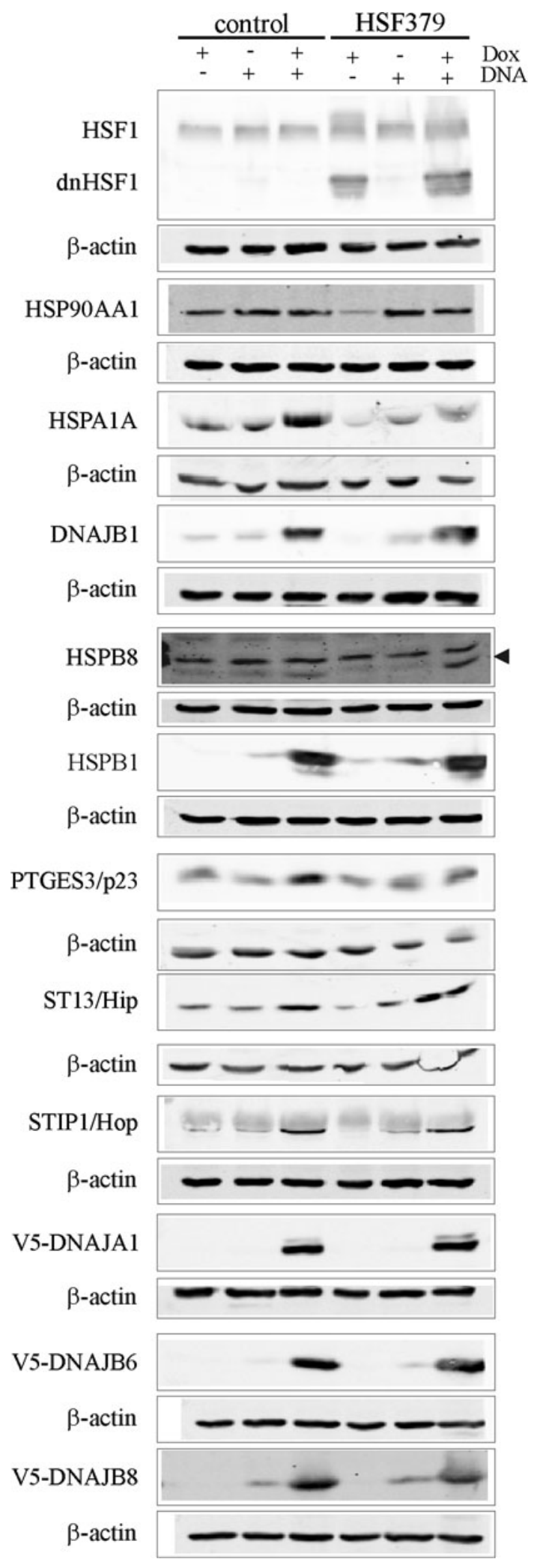

DNAJB1 and another co-chaperone is also implied by the lack of a phenotype of the DNAJB1 knock-out mouse, which has only a minor deficiency in acquired thermotolerance [63]. In the case of the progesterone receptor, it has
Fig. 8 Levels of exogenous expression of (co-)chaperones. Expression plasmids for the (co-)chaperones indicated on the left were transfected into either HEK-cDNA cells (control) or HEK-HSF379 cells (+DNA) and expression was induced by adding doxycyclin (+Dox), except for HSP90AA1, of which expression is constitutive. Protein levels were determined by western blotting and staining with the corresponding antibody (see "Materials and methods"). The arrowhead indicates HSPB8. Note that, in the case of DNAJA1, DNAJB6 and DNAJB8 antibody to the V5-tag carried by the exogenous proteins was used; the endogenous protein is thus not detected. $\beta$-actin was used as a loading control

Table 4 Relative effect of exogenous expression of (co-)chaperones on glucocorticoid signaling in HEK-cDNA5 cells

\begin{tabular}{llll}
\hline Gene name & \multicolumn{3}{l}{ Dexamethasone $(\mathrm{nM})$} \\
\cline { 2 - 4 } & 10 & 100 & 1,000 \\
\hline (Co-)chaperones/control & & \\
HSPB1 & $1.0 \pm 0.1$ & $0.8 \pm 0.1$ & $0.9 \pm 0.2$ \\
HSPB8 & $0.8 \pm 0.1$ & $0.7 \pm 0.1$ & $0.8 \pm 0.1$ \\
HSP90AA1 & $1.1 \pm 0.3$ & $0.9 \pm 0.2$ & $0.9 \pm 0.3$ \\
PTGES3 & $0.8 \pm 0.1$ & $0.7 \pm 0.1$ & $0.6 \pm 0.1$ \\
STIP1 & $1.0 \pm 0.1$ & $0.9 \pm 0.1$ & $0.9 \pm 0.2$ \\
ST13 & $1.1 \pm 0.1$ & $0.9 \pm 0.1$ & $1.1 \pm 0.2$ \\
DNAJA1 & $1.0 \pm 0.1$ & $1.0 \pm 0.1$ & $1.1 \pm 0.1$ \\
DNAJB1 & $1.0 \pm 0.1$ & $1.0 \pm 0.1$ & $1.0 \pm 0.2$ \\
DNAJB6 & $0.9 \pm 0.1$ & $0.8 \pm 0.1$ & $0.8 \pm 0.1$ \\
DNAJB8 & $0.9 \pm 0.2$ & $0.9 \pm 0.1$ & $0.8 \pm 0.1$ \\
HSPA1A & $0.8 \pm 0.2$ & $0.8 \pm 0.2$ & $1.0 \pm 0.4$ \\
\hline
\end{tabular}

The values represent av. $\pm \mathrm{SD}$

been shown that either DNAJA1 or DNAJB1 can assist in folding but by distinct mechanisms. DNAJA1 bound tightly to the progesterone receptor while DNAJB1 did so only transiently [64].

Heat stress or expression of a dominant-positive HSF1 mutant potentiates the glucocorticoid response [43, 44], suggesting that the chaperone network is limiting for this response in normal cells. The chaperone network is also limiting for luciferase refolding as this can be boosted by overexpressing Hsp70, an effect which can be blocked by expressing a dominant-negative DNAJB1 mutant [65]. In contrast, exogenous expression of single (co-)chaperones did not enhance the sensitivity of HEK-cDNA cells to dexamethasone, indicating that, unlike luciferase refolding, it is either a combination of chaperones and co-chaperones that is limiting or that other proteins are involved. In addition, exogenous expression of a dominant negative DNAJB1 mutant did not significantly block the dexamethasone response (data not shown).

Maintaining proteostasis during ageing is expected to prevent or at least ameliorate age-related protein folding and inflammatory disease $[6,41]$. One possible approach is 
to prevent the decline in HSF1 activity either by targeting HSF1 directly or by targeting longevity-related factors which control HSF1 activity such as SIRT1 [38]. One potential drawback of this approach is that HSF1 also increases the risk of cancer, another often age-related disease [60]. An alternative is to maintain the capacity of the chaperoning network by boosting a single (co-)chaperones. The results reported here show that DNAJA1 and DNAJB1 are promising targets. The finding that MEF cells do have wild-type levels of DNAJB1 in the absence of HSF1 shows that HSF1 can be bypassed in the transcriptional regulation of the DNAJB1 gene.

Acknowledgments We thank Saskia Polling and Femke Philips for technical support, Dr. Jurre Hageman for DNAJ expression constructs and Dr. A. Zantema for the HSPB1 antibody. This work was financially supported by IOP Genomics project number IGE03018.

Open Access This article is distributed under the terms of the Creative Commons Attribution Noncommercial License which permits any noncommercial use, distribution, and reproduction in any medium, provided the original author(s) and source are credited.

\section{References}

1. Kregel KC (2002) Molecular biology of thermoregulation: invited review: heat shock proteins: modifying factors in physiological stress responses and acquired thermotolerance. J Appl Physiol 92:2177-2186

2. Queitsch C, Sangster TA, Lindquist S (2002) Hsp90 as a capacitor of phenotypic variation. Nature 417:618-624

3. Rutherford SL, Lindquist S (1998) Hsp90 as a capacitor for morphological evolution. Nature 396:336-342

4. Slavotinek A, Biesecker LG (2003) Genetic modifiers in human development and malformation syndromes, including chaperone proteins. Hum Mol Genet 12:45R-50R

5. Zhang K, Kaufman RJ (2006) The unfolded protein response: a stress signaling pathway critical for health and disease. Neurology 66:S102-S109

6. Balch WE, Morimoto RI, Dillin A, Kelly JW (2008) Adapting proteostasis for disease intervention. Science 319:916-919

7. Powers ET, Morimoto RI, Dillin A, Kelly JW, Balch WE (2009) Biological and chemical approaches to diseases of proteostasis deficiency. Annu Rev Biochem 78:959-991

8. Broadly SA, Hartl FU (2009) The role of molecular chaperones in human misfolding diseases. FEBS Lett 583:2647-2653

9. Vos MJ, Hageman J, Carra S, Kampinga HH (2008) Structural and functional diversities between members of the human HSPB, HSPH, HSPA, and DNAJ chaperone families. Biochemistry 47:7001-7011

10. Qiu X, Shao Y, Miao S, Wang L (2006) The diversity of the DnaJ/Hsp40 family, the crucial partners for Hsp70 chaperones. Cell Mol Life Sci 63:2560-2570

11. Kampinga H, Hageman J, Vos M, Kubota H, Tanguay R, Bruford E, Cheetham M, Chen B, Hightower L (2009) Guidelines for the nomenclature of the human heat shock proteins. Cell Stress Chaperones 14:105-111

12. Fritha H, William SN, Richard Z, Michael EC, Gregory LB (2005) Not all J domains are created equal: Implications for the specificity of Hsp40-Hsp70 interactions. Prot Sci 14:1697-1709
13. Satyal SH, Schmidt E, Kitagawa K, Sondheimer N, Lindquist S, Kramer JM, Morimoto RI (2000) Polyglutamine aggregates alter protein folding homeostasis in Caenorhabditis elegans. Proc Natl Acad Sci USA 97:5750-5755

14. Bailey CK, Andriola IFM, Kampinga HH, Merry DE (2002) Molecular chaperones enhance the degradation of expanded polyglutamine repeat androgen receptor in a cellular model of spinal and bulbar muscular atrophy. Hum Mol Genet 11: $515-523$

15. Chan HYE, Warrick JM, Gray-Board GL, Paulson HL, Bonini NM (2000) Mechanisms of chaperone suppression of polyglutamine disease: selectivity, synergy and modulation of protein solubility in Drosophila. Hum Mol Genet 9:2811-2820

16. Kobayashi Y, Kume A, Li M, Doyu M, Hata M, Ohtsuka K, Sobue G (2000) Chaperones Hsp70 and Hsp40 suppress aggregate formation and apoptosis in cultured neuronal cells expressing truncated androgen receptor protein with expanded polyglutamine tract. J Biol Chem 275:8772-8778

17. Nollen EAA, Brunsting JF, Song J, Kampinga HH, Morimoto RI (2000) Bag1 functions in vivo as a negative regulator of Hsp70 chaperone activity. Mol Cell Biol 20:1083-1088

18. Åkerfelt M, Trouillet D, Mezger V, Sistonen L (2007) Heat shock factors at a crossroad between stress and development. Ann NY Acad Sci 1113:15-27

19. Shamovsky I, Nudler E (2008) New insights into the mechanism of heat shock response activation. Cell Mol Life Sci 65:855-861

20. Voellmy R (2004) On mechanisms that control heat shock transcription factor activity in metazoan cells. Cell Stress Chaperones 9:122-133

21. Christians E, Davis AA, Thomas SD, Benjamin IJ (2000) Embryonic development: maternal effect of Hsf1 on reproductive success. Nature 407:693-694

22. Izu H, Inouye S, Fujimoto $M$, Shiraishi K, Naito K, Nakai A (2004) Heat shock transcription factor 1 is involved in qualitycontrol mechanisms in male germ cells. Biol Reprod 70:18-24

23. Santos SD, Saraiva MJ (2004) Enlarged ventricles, astrogliosis and neurodegeneration in heat shock factor 1 null mouse brain. Neuroscience 126:657-663

24. Takaki E, Fujimoto M, Sugahara K, Nakahari T, Yonemura S, Tanaka Y, Hayashida N, Inouye S, Takemoto T, Yamashita H, Nakai A (2006) Maintenance of olfactory neurogenesis requires HSF1, a major heat shock transcription factor in mice. J Biol Chem 281:4931-4937

25. Xiao X, Zuo X, Davis AA, McMillan DR, Curry BB, Richardson JA, Benjamin IJ (1999) HSF1 is required for extra-embryonic development, postnatal growth and protection during inflammatory responses in mice. EMBO J 18:5943-5952

26. Zhang Y, Huang L, Zhang J, Moskophidis D, Mivechi NF (2002) Targeted disruption of hsf1 leads to lack of thermotolerance and defines tissue-specific regulation for stress-inducible Hsp molecular chaperones. J Cell Biochem 86:376-393

27. Inouye S, Izu H, Takaki E, Suzuki H, Shirai M, Yokota Y, Ichikawa H, Fujimoto M, Nakai A (2004) Impaired IgG production in mice deficient for heat shock transcription factor 1. J Biol Chem 279:38701-38709

28. Tchenio T, Havard M, Martinez LA, Dautry F (2006) Heat shockindependent induction of multidrug resistance by heat shock factor 1. Mol Cell Biol 26:580-591

29. Inouye S, Fujimoto M, Nakamura T, Takaki E, Hayashida N, Hai T, Nakai A (2007) Heat shock transcription factor 1 opens chromatin structure of interleukin-6 promoter to facilitate binding of an activator or a repressor. J Biol Chem 282:33210-33217

30. Khaleque MA, Bharti A, Gong J, Gray PJ, Sachdev V, Ciocca DR, Stati A, Fanelli M, Calderwood SK (2007) Heat shock factor 1 represses estrogen-dependent transcription through association with MTA1. Oncogene 27:1886-1893 
31. Fawcett T, Sylvester S, Sarge K, Morimoto R, Holbrook N (1994) Effects of neurohormonal stress and aging on the activation of mammalian heat shock factor 1 . J Biol Chem 269: 32272-32278

32. Heydari AR, You S, Takahashi R, Gutsmann-Conrad A, Sarge KD, Richardson A (2000) Age-related alterations in the activation of heat shock transcription factor 1 in rat hepatocytes. Exp Cell Res 256:83-93

33. Jurivich DA, Choo M, Welk J, Qiu L, Han K, Zhou X (2005) Human aging alters the first phase of the molecular response to stress in T-cells. Exp Gerontol 40:948-958

34. Liu A, Lin Z, Choi H, Sorhage F, Li B (1989) Attenuated induction of heat shock gene expression in aging diploid fibroblasts. J Biol Chem 264:12037-12045

35. Njemini R, Abeele MV, Demanet C, Lambert M, Vandebosch $\mathrm{S}$, Mets T (2002) Age-related decrease in the inducibility of heat-shock protein 70 in human peripheral blood mononuclear cells. J Clin Immunol 22:195-205

36. Njemini R, Lambert M, Demanet C, Mets T (2006) The effect of aging and inflammation on heat shock protein 27 in human monocytes and lymphocytes. Exp Gerontol 41:312-319

37. Rao DV, Watson K, Jones GL (1999) Age-related attenuation in the expression of the major heat shock proteins in human peripheral lymphocytes. Mech Ageing Dev 107:105-118

38. Westerheide SD, Anckar J, Stevens SM Jr, Sistonen L, Morimoto RI (2009) Stress-inducible regulation of heat shock factor 1 by the deacetylase SIRT1. Science 323:1063-1066

39. Fujimoto M, Takaki E, Hayashi T, Kitaura Y, Tanaka Y, Inouye S, Nakai A (2005) Active HSF1 significantly suppresses polyglutamine aggregate formation in cellular and mouse models. J Biol Chem 280:34908-34916

40. Vacher C, Garcia-Oroz L, Rubinsztein DC (2005) Overexpression of yeast hsp104 reduces polyglutamine aggregation and prolongs survival of a transgenic mouse model of Huntington's disease. Hum Mol Genet 14:3425-3433

41. Calderwood SK, Murshid A, Prince T (2009) The shock of aging: molecular chaperones and the heat shock response in longevity and aging - a mini-review. Gerontology 55:550-558

42. Grad I, Picard D (2007) The glucocorticoid responses are shaped by molecular chaperones. Mol Cell Endocrinol 275:2-12

43. Sanchez E, Hu J, Zhong S, Shen P, Greene M, Housley P (1994) Potentiation of glucocorticoid receptor-mediated gene expression by heat and chemical shock. Mol Endocrinol 8:408-421

44. Jones TJ, Li D, Wolf IM, Wadekar SA, Periyasamy S, Sanchez ER (2004) Enhancement of glucocorticoid receptor-mediated gene expression by constitutively active heat shock factor 1 . Mol Endocrinol 18:509-520

45. Wang J-H, Yao M-Z, Gu J-F, Sun L-Y, Shen Y-F, Liu X-Y (2002) Blocking HSF1 by dominant-negative mutant to sensitize tumor cells to hyperthermia. Biochem Biophys Res Commun 290:1454-1461

46. Hageman J, Kampinga H (2009) Computational analysis of the human HSPH/HSPA/DNAJ family and cloning of a human HSPH/HSPA/DNAJ expression library. Cell Stress Chaperones $14: 1-21$

47. Doerwald L, Onnekink C, van Genesen ST, de Jong WW, Lubsen NH (2003) Translational thermotolerance provided by small heat shock proteins is limited to cap-dependent initiation and inhibited by 2-aminopurine. J Biol Chem 278:49743-49750
48. Doerwald L, van Genesen ST, Onnekink C, Marín-Vinader L, de Lange F, de Jong WW, Lubsen NH (2006) The effect of alphaB-crystallin and Hsp27 on the availability of translation initiation factors in heat-shocked cells. Cell Mol Life Sci 63: 735-743

49. Voellmy R (2005) Dominant-positive and dominant-negative heat shock factors. Methods 35:199-207

50. Hageman J (2008) The human HSP70/HSP40 chaperone family. Thesis, University of Groningen, Groningen, The Netherlands

51. Wandinger SK, Richter K, Buchner J (2008) The Hsp90 chaperone machinery. J Biol Chem 283:18473-18477

52. Cooper LF, Uoshima K, Guo Z (2000) Transcriptional regulation involving the intronic heat shock element of the rat hsp27 gene. Biochim Biophys Acta 1490:348-354

53. Trinklein ND, Murray JI, Hartman SJ, Botstein D, Myers RM (2004) The role of heat shock transcription factor 1 in the genome-wide regulation of the mammalian heat shock response. Mol Biol Cell 15:1254-1261

54. Holcik M, Sonenberg N (2005) Translational control in stress and apoptosis. Nat Rev Mol Cell Biol 6:318-327

55. McMillan DR, Xiao X, Shao L, Graves K, Benjamin IJ (1998) Targeted disruption of heat shock transcription factor 1 abolishes thermotolerance and protection against heat-inducible apoptosis. J Biol Chem 273:7523-7528

56. Pearl L, Prodromou C, Workman P (2008) The Hsp90 molecular chaperone: an open and shut case for treatment. Biochem $\mathrm{J}$ 410:439-453

57. Wochnik GM, Young JC, Schmidt U, Holsboer F, Hartl FU, Rein $\mathrm{T}$ (2004) Inhibition of GR-mediated transcription by $\mathrm{p} 23$ requires interaction with Hsp90. FEBS Lett 560:35-38

58. Freeman BC, Yamamoto KR (2002) Disassembly of transcriptional regulatory complexes by molecular chaperones. Science 296:2232-2235

59. Page TJ, Sikder D, Yang LLP, Wolfinger RD, Kodadek T, Thomas RS (2006) Genome-wide analysis of human HSF1 signaling reveals a transcriptional program linked to cellular adaptation and survival. Mol Biosyst 2:627-639

60. Dai C, Whitesell L, Rogers AB, Lindquist S (2007) Heat shock factor 1 is a powerful multifaceted modifier of carcinogenesis. Cell 130:1005-1018

61. Xie Y, Chen C, Stevenson MA, Auron PE, Calderwood SK (2002) Heat shock factor 1 represses transcription of the IL-1beta gene through physical interaction with the nuclear factor of interleukin 6. J Biol Chem 277:11802-11810

62. Dittmar KD, Banach M, Galigniana MD, Pratt WB (1998) The role of DnaJ-like proteins in glucocorticoid receptor hsp90 heterocomplex assembly by the reconstituted hsp90 p60 hsp70 foldosome complex. J Biol Chem 273:7358-7366

63. Uchiyama Y, Takeda N, Mori M, Terada K (2006) Heat shock protein $40 / \mathrm{DjB} 1$ is required for thermotolerance in early phase. J Biochem 140:805-812

64. Cintron NS, Toft D (2006) Defining the requirements for Hsp40 and $\mathrm{Hsp} 70$ in the Hsp90 chaperone pathway. J Biol Chem 281:26235-26244

65. Michels AA, Kanon B, Bensaude O, Kampinga HH (1999) Heat shock protein (Hsp) 40 mutants inhibit Hsp70 in mammalian cells. J Biol Chem 274:36757-36763 